\title{
Analisis Senyawa Aktif dalam Cacing Spesies Lokal dan Efek Antiinflamasi
}

\author{
Arysca Wisnu Satria ${ }^{1, *}$, Andy Darmawan ${ }^{2}$, Irwan Sudarmanto ${ }^{2}$ \\ ${ }^{1} J u r u s a n$ Teknologi Proses Hayati, Institut Teknologi Sumatera, Lampung Selatan \\ 2Jurusan Sains, Institut Teknologi Sumatera, Lampung Selatan \\ 1, ${ }^{*}$ E-mail Corresponding: arysca.wisnu@tk.itera.ac.id \\ Diterima: 30 Maret 2020 - Disetujui: 30 April 2020 - Dipublikasi: 05 Mei 2020 \\ () 2020 Jurusan Biologi FMIPA Universitas Halu Oleo Kendari, Indonesia.
}

\begin{abstract}
Inflammation is a common health problem experienced by humans. Besides using drugs, people also use animals to treat the inflammation, such as earthworms. This study aims to analyze the content of active substances found in earthworm, commonly obtained in Indonesia as an anti-inflammatory drug. The extraction of active substances was carried out by the maceration method using hexane, chloroform, and ethyl acetate fraction with a ratio of 0.5:0.3:0.2. The fractionation results using hexane and ethanol are obtained 3.705 grams and 2.046 grams extracts respectively. Furthermore, each extract was tested using the Gas Chromatography-Mass Spectrophotometer (GC-MS) method and the result are almost uniform but different concentrations. The result of the worm taxonomic identification is the species Eudrilus eugeniae. The compounds identified are the cycloheptasiloxane group, which consists of three types, i.e. cyclohetasiloxane tertradecamethyl, cycloheptasiloxane hexadecamethyl, and cycloheptasiloxane octadecamethyl. These cycloheptasiloxanes compounds are compounds that have antibacterial, anticoagulant and anti-inflammatory properties.
\end{abstract}

Key words: anti-inflammation, extraction, Eudrilus eugeniae, cycloheptasiloxane

\section{Abstrak}

Radang atau inflamasi merupakan masalah kesehatan yang umum dialami oleh manusia. Selain menggunakan obat-obatan untuk mengobati radang, manusia juga menggunakan hewan seperti cacing tanah. Penelitian ini bertujuan untuk menganalisis kandungan zat aktif yang terdapat pada cacing tanah yang umum diperoleh di Indonesia sebagai bahan obat antiradang. Ekstraksi zat aktif dalam cacing tanah dilakukan dengan metode maserasi menggunakan pelarut heksan, kloroform dan etil asetat dengan perbandingan 0,5:0,3:0,2. Hasil fraksinasi menggunakan pelarut heksan dan etanol berturut-turut sebesar 3,705 dan 2,046 gram. Selanjutnya masing-masing ekstrak tersebut diuji kandungan senyawanya menggunakan metode Gas Chromatography-Mass Spectrophotometer (GC$M S$ ) menghasilkan senyawa yang hampir seragam namun berbeda konsentrasinya. Hasil identifikasi taksonomi cacing yang diperoleh adalah spesies Eudrilus eugeniae. Sedangkan senyawa yang teridentifikasi adalah golongan cycloheptasiloxane, yang terdiri dari tiga jenis, yaitu: cyclohetasiloxane tertradecamethyl, cycloheptasiloxane hexadecamethyl, dan cycloheptasiloxane octadecamethyl. Senyawa golongan cycloheptasiloxane ini adalah senyawa yang termasuk antibakteri, antikoagulan dan antiinflamasi/antiradang.

Kata kunci: antiinflamasi, ekstraksi, Eudrilus eugeniae, cycloheptasiloxane 


\section{PENDAHULUAN}

Radang merupakan masalah kesehatan yang umum dialami oleh manusia. Umumnya pengobatan radang menggunakan senyawa aspirin dan turunan diklofenak sebagai obat antiradang. Dalam bidang farmasi, senyawa aspirin dan turunan diklofenak biasa diperoleh/diekstrak dari tumbuhan. Selain menggunakan obat-obatan, manusia juga menggunakan hewan sebagai bahan alternatif untuk mengobati radang, seperti cacing tanah.

Dewasa ini banyak cacing tanah dibudidayakan untuk berbagai keperluan. Selain sebagai pengurai tanah yang baik, cacing tanah juga digunakan sebagai pakan ternak atau pakan ikan. Cacing tanah dipercaya memiliki khasiat untuk menurunkan demam yang diakibatkan oleh radang. Di sebagian kalangan masyarakat Indonesia, cacing tersebut dibersihkan, lalu dikeringkan dan dikemas dalam bentuk kapsul. Cacing tanah yang biasa digunakan oleh masyarakat Indonesia tergolong ke dalam subkelas Oligochaeta dan bersifat terrestrial (Brusca and Brusca 2003, dan Ruggiero et al. 2015).

Para peneliti telah melakukan identifikasi zat aktif yang terdapat di dalam cacing tanah sebagai bahan obat-obatan. Namun cacing yang digunakan dalam penelitian terdahulu lebih banyak menggunakan cacing tanah non-oriental sehingga cacing tersebut sulit diperoleh di Indonesia.

Secara empiris di Indonesia, cacing tanah jenis Lumbricus rubellus sering digunakan untuk pasien penyakit typhus dan saluran pernafasan (Kusmana, 2015). Demikian juga beberapa penyakit yang disebabkan oleh bakteri patogen, di antaranya: radang tenggorokan, tuberculosis, dan difteri telah dicoba dapat disembuhkan dengan menggunakan ekstrak cacing tanah.
Cacing tanah yang dikeringkan juga dilaporkan dapat dipakai untuk menyembuhkan luka, bisul, wasir, radang tenggorokan, rematik, sakit telinga, batuk kronis, bronkhitis, difteri dan sakit kuning. Cacing yang diekstraksi dengan minyak dipakai untuk menyembuhkan hemiplegia dan kelumpuhan (Ismail et al. 1992). Cacing tanah banyak dikembangkan di beberapa negara dan dimanfaatkan secara maksimal sebagai bahan kosmetik.

Cacing tanah mengandung protein yang cukup tinggi, yaitu antara $58-71 \%$ berat kering. Ada juga yang melaporkan bahwa kandungan protein mencapai $84,5 \%$. Kandungan asam aminonya yang lengkap serta terdapat juga lemak, kaborhidrat, kalsium, fosfor, sulfur, asam suksinat dan asam hialuronat (Fu-Xia et al. 1992). Xiang et al. (2006) telah mengidentifikasi zat aktif dalam cacing tanah dari cacing Metaphire californica dan mendapati 17 macam asam amino dalam spesies tersebut seperti yang ditunjukkan oleh Tabel 1.

Tabel 1. Kandungan asam amino dalam cacing tanah

\begin{tabular}{clc}
\hline No & Jenis asam amino & Konsentrasi (\%) \\
\hline 1 & Plenylalanine & 1,23 \\
2 & Alanine & 1,59 \\
3 & Methionine & 1,33 \\
4 & Proline & 1,04 \\
5 & Glycine & 1,47 \\
6 & Glutamic acid & 3,75 \\
7 & Cystine & 0,78 \\
8 & Arginine & 1,85 \\
9 & Lysine & 1,84 \\
10 & Tyrosine & 0,92 \\
11 & Leucine & 2,16 \\
12 & Serine & 1,27 \\
13 & Threoine & 1,21 \\
14 & Aspartic acid & 2,68 \\
15 & Valine & 1,56 \\
16 & Isoleucine & 1,44 \\
17 & Histidine & 0,56 \\
\hline (Sumber : Xiang, Changguo et al., 2006)
\end{tabular}

Secara umum cacing tanah dilaporkan memiliki pengaruh sebagai antiperetik, antispasmodik, antidiuretik, antiasmatik, 
antihipertensi, antialergi (Fu-Xia et al. 1992) dan antiinflamasi (Ismail et al. 1992). Santoso (2002) menggunakan ekstrak Peretima aspergillum yang mampu mencegah kenaikan suhu tubuh tikus putih setelah penyuntikan vaksin campak. Dari indentifikasi fraksi aktif dengan uji senyawa metabolit sekunder menggunakan Spektoskopi UV-Vis dan IR menunjukkan bahwa kedua fraksi mengandung alkaloid. Penelitian lain juga dilakukan oleh Mathur et al. (2011) menggunakan cacing Eudrilus eugeniae yang diekstraksi menggunakan petroleum eter memiliki kesamaan dengan aktifitas antiinflamasi pada aspirin. Sementara itu, Balamurungan et al. (2009) menggunakan ekstrak cacing Lampito mauritii (Kinberg) yang dicobakan menggunakan tikus Wistar dan hasilnya menunjukkan secara signifikan adanya penurunan hyperpyrexia yang menunjukkan adanya antiinflamasi dan antipyretic yang mirip dengan glycoprotein complex (G-90).

Chen et al. (2007) dalam penelitiannya berhasil mengisolasi fibrinolytic enzim dari Esenia fetida yang memiliki aktivitas antitumor. Earthworm fibrinolytic enzyme (EFE) adalah kompleks protein enzim yang terdistribusi secara luas pada saluran pencernaan cacing. Studi yang dilakukan secara in vitro dan in vivo pada sel hepatoma manusia menunjukkan bahwa adanya aktivitas signifikan pada sel tersebut. Hal ini disebabkan enzim tersebut dapat menginduksi apoptosis sel hepatoma dan menghambat ekspresi MMP-2, sehingga memiliki pontesi untuk menyembuhkannya.

Sementara itu, di Indonesia telah banyak dilakukan budidaya cacing tanah dari jenis yang umum dibudidayakan. Akan tetapi para peternak cacing tanah di Indonesia cenderung melakukan identifikasi hanya melalui karakter eksternal yang mengakibatkan hasil indentifikasi tersebut tidaklah valid. Tujuan penelitian ini adalah mengidentifikasi cacing tanah hingga karakter internal dengan menggunakan cacing yang diperoleh dari kultur di Indonesia, sehingga diketahui jenis spesies cacing yang valid. Tujuan lebih lanjut adalah untuk mencari senyawa aktif yang memiliki efek antiinflamasi.

\section{METODE PENELITIAN Waktu dan Tempat}

Penelitian ini dilakukan di Laboratorium Kimia Dasar Institut Teknologi Sumatera pada bulan April-Oktober 2019. Uji senyawa target dilakukan di UPT Laboratorium Terpadu Universitas Lampung, sedangkan uji antiinflamasi in vitro dilaksanakan di Laboratorium Kimia Analitik Universitas Malahayati, Lampung.

\section{Alat dan Bahan}

Peralatan yang digunakan alat-alat gelas neraca/timbangan, kertas saring, rotary evaporator, Gas ChromatographyMass Spectrophotometer (GC-MS) Analysis, dan ELISA reader. Material utama yang digunakan dalam penelitian ini adalah cacing tanah yang diperoleh dari peternakan di Mlati, Kabupaten Sleman, D.I. Yograkarta. Bahan lain berupa etanol, heksan, kloroform, etil asetat dan plat KLT dari PT Merck Jakarta, sedangkan Eliza COX-2 Kit dari PT Indogen Jakarta.

Cacing tanah yang diambil dari peternakan dipilih beberapa yang sehat untuk diidentifikasi dengan menggunakan buku identifikasi taksonomi (Blakemore, 2010) sehingga diketahui jenis spesiesnya. Setelah selesai diidentifikasi cacing tanah selanjutnya dibersihkan dari kotoran dan dimatikan dengan cara merendam dalam larutan eter. Cacing tanah kemudian dikeringkan dalam oven selama 4 jam pada suhu $60^{\circ} \mathrm{C}$ kemudian digiling hingga membentuk serbuk dan diayak.

Ekstraksi bahan aktif dari cacing tanah dilakukan secara maserasi, yaitu 
digunakan pelarut etanol dan heksan dengan perbandingan berat masingmasing sampel dan jumlah pelarut $(\mathrm{b} / \mathrm{v})$ adalah 1:10. Setelah 24 jam selanjutnya maserat dipisahkan dengan menyaring filtrat dengan menggunakan kertas saring Whatman. Maserat selanjutnya difraksinasi menggunakan heksan, kloroform dan etil asetat masing masing $200 \mathrm{~mL}$. Fraksi yang diperoleh selanjutnya diuapkan menggunakan rotary evaporator hingga diperoleh ekstrak kental. Ekstrak kental selanjutnya ditimbang dan dimasukkan botol sampel untuk digunakan dalam uji senyawa target dan uji aktivitas antiinflamasi secara in vitro.

\section{Analisis Data}

Ekstrak selanjutnya diuji daya inhibisinya terhadap enzim COX-2. Uji daya inhibisi dilakukan dengan metode ELISA (Enzyme Linked Immunosorbent Assay), dengan menggunakan COX Inhibitor Screening Assay Kit. Selanjutnya hasil reaksi inhibisi antara sampel cacing tanah terhadap enzim COX-2 dibaca serapannya menggunakan ELISA reader.

Aktivitas anti inflamasi ekstrak cacing tanah dapat diketahui dengan besarnya nilai \% inhibisi sampel cacing tanah terhadap aktivitas enzim siklooksigenase-2 (COX-2). Penghambatan enzim COX-2 dapat digunakan untuk mengetahui aktivitas antiinflamasi suatu bahan (sampel) mengingat enzim COX-2 memiliki peranan penting dalam mensintesis prostaglandin yang berperan penting dalam proses peradangan (Dannhardt and Laufer , 2000).

Identifikasi komponen zat aktif dilakukan terhadap fraksi cacing tanah yang memiliki potensi daya hambat/inhibisi enzim COX-2 yang paling tinggi. Identifikasi komponen fraksi cacing tanah menggunakan metode Gas Chromatograpy-Mass Spectrophotometer
(GC-MS) menggunakan eluen yang sesuai. Eluen diperoleh dengan melakukan serangkaian optimasi.

Pengujian sampel dilakukan sebanyak tiga kali hingga diperoleh kromatogram yang baik. Kromatogram yang peroleh selanjutnya diidentifikasi hingga diperoleh komponen penyusun fraksi cacing tanah yang paling berpotensi sebagai antiinflamasi.

\section{HASIL DAN PEMBAHASAN}

Hasil analisis taksonomi menggunakan buku identifikasi menunjukkan bahwa jenis cacing tanah adalah spesies Eudrilus eugeniae. Menurut Suthar (2008), Eudrilus eugeniae adalah termasuk jenis cacing composting yang potensial digunakan untuk restorasi tanah. Sifat-sifat cacing tanah jenis ini adalah memiliki umur kedewasaan seksual yang cepat, kemampuam menghasilkan keturunan yang banyak, dan memiliki waktu inkubasi yang pendek (Padmavathiamma et al. 2008). Cacing ini juga merupakan kandidat utama sebagai sumber protein dan memiliki profil asam amino yang setara dengan tepung ikan (Dedeke et al. 2010).

Sementara itu, dari hasil maserasi menggunakan pelarut heksan dan etanol diperoleh volume ekstak cacing berturutturut sebesar 3,705 dan 2,046 gram. Sedangkan pada hasil uji identifikasi menggunakan metode GC-MS menunjukkan adanya senyawa yang hampir seragam namun berbeda konsentrasi. Senyawa yang teridentifikasi adalah golongan cycloheptasiloxane, yang terdiri dari tiga jenis, yaitu: cycloheptasiloxane tertradecamethyl, cycloheptasiloxane hexadecamethyl, dan cycloheptasiloxane octadecamethyl. Hasil analisis rinci kandungan senyawa dengan metode GC-MS pada masing-masing ekstrak cacing tersebut dapat dilihat pada Gambar 1 - 2. 


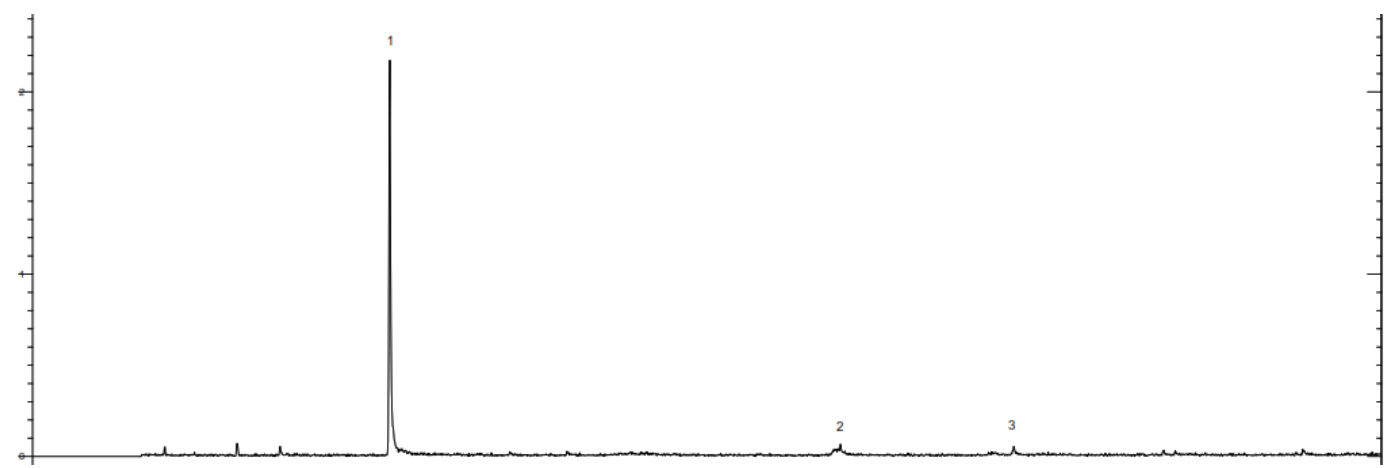

Gambar 1. Kromatogram GC-MS ekstrak cacing Eudrilus eugeniae untuk pelarut etanol.

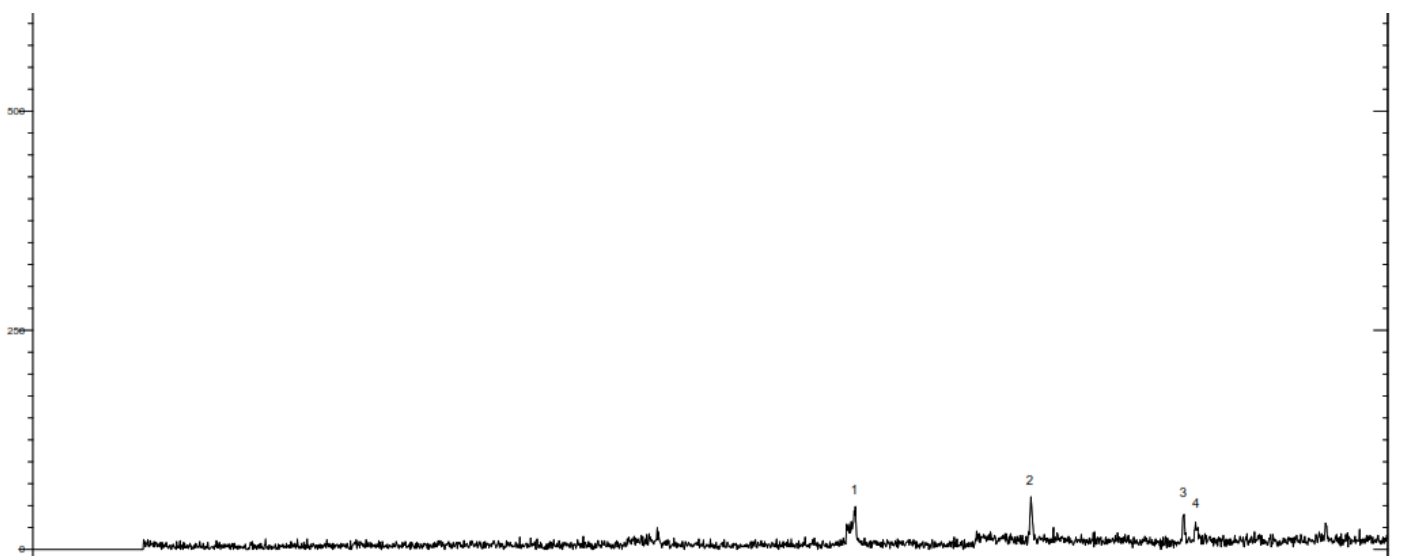

Gambar 2. Kromatogram GC-MS ekstrak cacing Eudrilus eugeniae untuk pelarut heksan.

Dari gambar pertama tersebut terlihat bahwa untuk pelarut etanol masih mengandung maserat heksan yang cukup besar, yaitu mencapai sebesar $95,17 \%$. Dengan kata lain, tingkat kemurnian pada pelarut etanol lebih sedikit dibanding pada pelarut heksan. Sedangkan pada gambar kromatogram pelarut heksan terlihat bahwa konsentrasi senyawa target cycloheptasiloxane tampak lebih murni.

Senyawa cycloheptasiloxane pada gambar pertama tampak pada puncak/peak yang kedua dan ketiga, yaitu cycloheptasiloxane tertradecamethyl dan cycloheptasiloxane hexadecamethyl. Sedangkan pada gambar kedua senyawa tersebut muncul pada puncak ke-1, 2 dan 3, berturut-turut yaitu: cycloheptasiloxane tertradecamethyl, cycloheptasiloxane hexadecamethyl, dan cycloheptasiloxane octadecamethyl.

Senyawa golongan cycloheptasiloxane ini menurut jurnal yang dipublikasikan oleh Hassan (2016) adalah senyawa yang termasuk antibakteri, antikoagulan dan antiinflamasi/antiradang. Oleh karena itu, untuk membuktikan adanya efek antiradang dari senyawa golongan cycloheptasiloxane diperlukan analisis lanjutan dari penelitian ini. Adapun analisis yang dilakukan menggunakan uji aktivitas melalui metode ELISA (Enzyme Linked Immunosorbent Assay), yaitu menggunakan COX Inhibitor Screening Assay Kit.

Saat ini dikenal dua isoenzim COX (siklooksigenase), yaitu COX-1 dan COX2. Enzim COX-1 berfungsi sebagai enzim constitutif, yaitu mengubah PGH2 menjadi berbagai jenis prostaglandin (PGI2, PGE2) dan tromboxan yang dibutuhkan dalam fungsi homeostatis. Enzim COX-2 yang terdapat di dalam sel-sel imun (makrofag dan lainnya), sel endotel pembuluh darah, dan fibroblas sinovial sangat mudah diinduksi oleh berbagai mekanisme sehingga akan mengubah $\mathrm{PGH} 2$ menjadi PGE2 yang berperan dalam proses 
inflamasi, yaitu nyeri dan demam. Oleh karena itu, COX-2 dikenal sebagai enzim inducible. Pada kenyataannya, baik COX-1 dan COX-2 adalah isoenzim yang dapat diinduksi. Enzim COX-1 mengkatalisis pembentukan prostaglandin baik yang bertanggung jawab untuk menjalankan fungsi-fungsi regulasi fisiologis. Sebaliknya, enzim COX-2 tidak ditemukan di jaringan pada kondisi normal, tetapi diinduksi oleh berbagai stimulus, seperti endotoksin, sitokin, mitogen, dan dihubungkan dengan produksi prostaglandin selama proses inflamasi, nyeri, dan respon piretik (Dannhardt and Laufer S 2010).

Enzim COX-2 dapat diinduksi apabila terdapat stimuli radang, mitogenesis atau onkogenesis. Mekanisme inflamasi yang terjadi di dalam tubuh bermula pada membran sel atau jaringan yang mengalami sakit atau terluka. Enzim fosfolipase dalam tubuh dari membran sel menghasilkan asam arakidonat yang nantinya akan melalui dua jalur tahapan, yaitu siklooksigenase dan lipoksigenase. Pada jalur siklooksigenase, akan terbentuk endoperoksida sedangkan pada jalur lipoksigenase terbentuk asam hidroperoksida.

Berdasarkan pengujian aktivitas antiinflamasi menggunakan uji penghambatan enzim siklooksigenasi (COX-2) menunjukkan bahwa sampel memiliki potensi sebagai antiinflamasi yang cukup baik. Bila dibandingkan dengan kontrol positif, yaitu Natrium diklofenak, potensi ekstrak cacing ini memang masih belum setara. Uji kandungan terhadap fraksi heksan dan etanol menunjukkan bahwa dalam sampel terdapat senyawa turunan siloksan yang sering digunakan sebagai agen inflamasi.

Senyawa siloksan dan turunannya merupakan senyawa yang umumnya terdapat dalam tanaman terutama bagian daun. Senyawa ini merupakan metabolit sekunder yang memiliki berbagai aktivitas bagi tanaman penghasilnya (Varothai et al. 2013). Senyawa turunan siloksan berhasil disintesis pada awal 1900-an dan telah diakui sebagai senyawa yang aman untuk bahan tambahan terutama kosmetik mengingat aktivitasnya sebagai emollient, humektan pengontrol viskositas (ICCS, 2016).

Dalam pengujian ini senyawa siloksan dan turunannya ternyata juga terdapat dalam cacing tanah. Senyawa ini bersifat hidrofobik, mengingat senyawa ini larut dalam pelarut nonpolar ( $\mathrm{n}$-heksan) hingga semipolar. Diduga senyawa-senyawa ini yang memberikan kontribusi dalam aktivitas antiinflamasi ekstrak cacing. Walaupun ada kemungkinan senyawa lain dalam sampel juga ikut terlibat dalam penghambatan enzim COX-2 (lihat tabel kandungan senyawa).

Tabel 2. Kandungan senyawa dalam Eudrilus eugeniae pada ekstrak etanol

\begin{tabular}{cclc}
\hline No & MW & \multicolumn{1}{c}{ Nama Senyawa } & \%Area \\
\hline 1 & 171 & Hexane,1,1-diethoxy & 95,17 \\
2 & 518 & Cycloheptasiloxane, tetradecamethyl & 2,54 \\
3 & 592 & Cyclooctasiloxane, hexadecamethyl & 2,28 \\
\hline
\end{tabular}

Tabel 3. Kandungan senyawa dalam Eudrilus eugeniae pada ekstrak heksan

\begin{tabular}{cclc}
\hline No & MW & \multicolumn{1}{c}{ Nama Senyawa } & \%Area \\
\hline 1 & 518 & Cycloheptasiloxane, tetradecamethyl & 32,25 \\
2 & 592 & Cyclooctasiloxane, hexadecamethyl & 38,65 \\
3 & 666 & Cyclononasiloxane, octadecamethyl & 14,04 \\
4 & 488 & Flufenoxuron & 15,06 \\
\hline
\end{tabular}


Beberapa hasil dari pengujian ini belum memberikan data yang memuaskan. Alasan yang pertama adalah karena sampel merupakan fraksi/ekstrak yang memiliki beberapa senyawa yang kemungkinan akan saling berinteraksi sehingga penghambatan aktivitas enzim COX-2 menjadi tidak maksimal. Kedua, kemungkinan juga terdapat senyawa yang bisa bersifat antiinflamasi namun karena kadarnya yang sangat kecil maka aktivitas antiinflamsi yang diperoleh juga kecil (lihat tabel kandungan dan kadar senyawa dalam ekstrak). Oleh karena itu perlu penelitian lebih lanjut untuk memurnikan senyawa aktif dalam sediaan cacing tanah dan menguji aktivitas antiinflamasi setiap senyawa yang ada.

\section{KESIMPULAN}

Hasil ekstraksi menggunakan pelarut heksan dan etanol dan identifikasi senyawanya menggunakan instrumen Gas Chromatography-Mass Spectrophotometer (GC-MS) pada peneilitian ini diperoleh senyawa yang hampir seragam, yaitu golongan cycloheptasiloxane. Senyawa golongan cycloheptasiloxane ini adalah senyawa yang termasuk antibakteri, antikoagulan dan antiinflamasi/antiradang.

\section{UCAPAN TERIMA KASIH}

Penulis menyampaikan terima kasih kepada Direktorat Riset dan Pengabdian Masyarakat Direktorat Jenderal Penguatan Riset dan Pengembangan Kementerian Riset, Teknologi, dan Pendidikan Tinggi atas dukungan pembiayaan penelitian ini melalui skema Penelitian Dosen Pemula Nomor 007/SP2H/LT/DRPM/2019.

\section{DAFTAR PUSTAKA}

Balamurugan, M., K. Parthasarathi, E. L. Cooper, and L. S. Ranganathan. 2009. "Anti-Inflammatory and AntiPyretic Activities of Earthworm
Extract-Lampito Mauritii (Kinberg)." Journal of Ethnopharmacology 121(2): 330-32.

Blakemore, R.J. 2010. "Cosmopolitan Eartworms - an Eco-Taxonomic Guide to the Peregrine Species of the World. $4^{\text {th }}$ ed" VermEcology

Brusca, R. C. and Brusca, G. J. 2003. "Invertebrates, 2nd ed." Sunderland: Sinauer Associates Inc.

Chen B., Hong C., Takahashi S., Imamura M., Okutani E., Zhang Z., and Chayama K., 2007 "Earthworm fibrinolytic enzyme: anti-tumor activity on human hepatoma cells in vitro and in vivo" Chin Med J (120): 898-904.

Dedeke, Gabriel A, Stephen O Owa, Kayode B Olurin, and Ogun State. 2010. "Amino Acid Profile of Four Earthworms Species from Nigeria." Agriculture and Biology Journal of North America 1(2): 97-102.

Fu-Xia, Z., Bao-Zhu, G. and Hui-Yun, W., 1992. The spermatocidal effects of earthworm extract and its effective constituents. Soil Biology and Biochemistry, 24(12), pp.12471251.

Hassan, S. W. M. 2016. "Antibacterial, anticoagulant and anti-inflammatory activities of marine Bacillus cereus S1," Journal of Pure and Applied Microbiology 10(2)2593-2606

International Comitee on Consumer Safety. Xyloxane. European Union: ISSN 1831-4767, 2016.

Ismail, S. A., Pulangdiran and Yegnanarayan R. 1992. "Antiinflamatory activity of earthworm extracts," Soil Biol, Biochem, (24):1253-1254.

Kusmana, M. 2015. Cacing tanah: peluang baru usaha ternak, info agribisnis," Sisipan Trubus, Trubus, Jakarta, vol. 26: 6-7.

Mathur, A., Verma, S.K., Singh, S. K., Prakash, A., Prasad, G.B.K.S. and Dua, V. K. 2011. "Anti-inflammatory 
activity of earthworm extracts," International Journal of Pharmaceutical Science and Reseach. 2(2): 278-281.

Padmavathiamma, Prabha K., Loretta Y. $\mathrm{Li}$, and Usha R. Kumari. 2008. "An Experimental Study of VermiBiowaste Composting for Agricultural Soil Improvement." Bioresource Technology 99(6): 1672-81.

Ruggiero, Michael A. et al. 2015. "A Higher Level Classification of All Living Organisms." PLOS ONE 10(4): 160.

Santoso, M. A. 2002. "Identifikasi ekstrak cacing tanah Lumbricus rubellus dan Peretima aspergillum yang memiliki efek antiperitik pada Tikus putih," Jurusan Kimia, Institut Pertanian Bogor.
Varothai, Supenya, Sunatra Nitayavardhana, and Kanokvalai Kulthanan. 2013. "Moisturizers for Patients with Atopic Dermatitis." Asian Pacific Journal of Allergy and Immunology 31(2): 91-98.

Suthar, Surindra. 2008. "Bioconversion of Post Harvest Crop Residues and Cattle Shed Manure into ValueAdded Products Using Earthworm Eudrilus Eugeniae Kinberg." Ecological Engineering 32(3): 20614.

Xiang, Changguo et al. 2006. "Changes in Diversity, Protein Content, and Amino Acid Composition of Earthworms from a Paddy Soil under Different Long-Term Fertilizations in the Tai Lake Region, China." Acta Ecologica Sinica 26(6): 1667-73. 